\title{
In Memoriam: Gaberell Drachman (27 June 1925 - 10 September 2014)
}

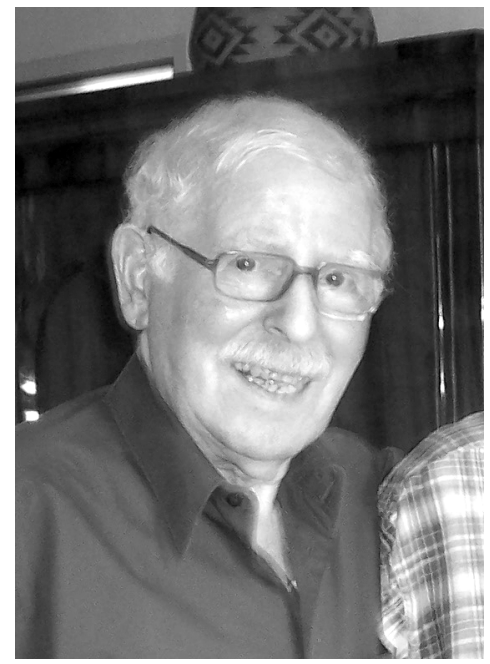

I am in a particularly difficult position reflecting here on the very sad news that Gaberell Drachman, Emeritus Professor at the University of Salzburg, passed away on September 10, 2014.

Gaberell Drachman was a distinguished professor of Linguistics at the University of Salzburg who loved and devoted his entire life to Greek linguistics and the Greek language, and who contributed substantially to the advancement of theoretical linguistics, producing a significant number of important publications, especially in the areas of syntax and phonology.

He started his academic life with a Ph. D. at the University of Chicago (1969), and then developed a brilliant career at the University of Salzburg, publishing a significant number of scholarly papers, and editing a number of books and journals. He was one of the founding co-editors of the Journal of Greek Linguistics in 2000 and continued work as a co-editor through this year.

Gaberell Drachman worked constantly at the cutting-edge of theoretical linguistics and his work inspired many young researchers and academics. 
He was a tireless academic who always brought important questions to the focal point of theoretical discussions covering a diverse range of topics.

For many years, he divided his life between Austria and Greece, and was always present at the most important conferences, particularly those on Greek Linguistics.

He was one of the first scholars to introduce modern linguistics into Greece and he never ceased to accept proposals for teaching and giving lectures in both Greece and Cyprus.

People who met Gaberell Drachman know that he was flamboyant and temperamental during his academic lectures, but also during his personal communication and discussions. Still, he had a youthful enthusiasm about new ideas and projects, and could catch up with almost every topic in current research.

Gaberell Drachman was not alone in this pilgrimage. He and his wife, Angeliki Malikouti-Drachman, also a linguist, conducted in-depth and pioneering research on many thorny issues in Greek morphology and phonology, such as, among others, stress, slogan chanting and speech rhythm, allomorphy, and assimilation and dissimilation phenomena.

Moreover, they were among the first to stress the importance of Modern Greek dialects and to turn the focus of research to many dialectal phenomena. They did extensive work on Cypriot Greek, Dodecanesian, and the Northern Greek dialects, always within the framework of the latest theoretical models, such as Distributed Morphology and Optimality Theory.

Unfortunately, a short message cannot cover the personality and the work of Gaberell Drachman. I consider myself very lucky to have had the chance to meet Gaberell, first as his student in the Salzburg Summer School, back in 1982, and then as a colleague at several conferences and scientific meetings.

On behalf of the scientific committee of the 6th Modern Greek Dialects and Linguistic Theory Conference, I had invited Gaberell Drachman to give a plenary talk at this year's gathering. Unfortunately, life runs faster, so the meeting had to be held in his honour, as a small tribute to his substantial contributions to theoretical linguistics, Greek linguistics and Modern Greek dialect studies.

I hope that this message can express some of our feelings for this respectful academic but at the same time gentle and nice personage of an unbelievable warmth and hospitality.

Angela Ralli

Director of the Laboratory of Modern Greek Dialects

Department of Philology, University of Patras 